\title{
Analisis Permasalahan Guru Terkait Pengembangan Perangkat Pembelajaran IPA Biologi Melalui Inkuiri Terbimbing
}

\author{
Budi Prasetiyo, Didimus Tanah Boleng, Makrina Tindangen* \\ Fakultas Keguruan dan Ilmu Pendidikan, Universitas Mulawarman \\ Jl. Kuaro, Gn. Kelua, Kec. Samarinda Ulu, Kabupaten Paser, Kalimantan Timur 75119 \\ E-mail: bprasetiyo212@gmail.com
}

\begin{abstract}
Abstrak
Penelitian ini bertujuan untuk mengetahui pemahaman guru terkait perangkat pembelajaran yangdikembangkan melalui model pembelajaran inkuiri terbimbing dan untuk mengetahui permasalahan apasaja yang dihadapi oleh guru saat mengembangkan perangkat pembelajaran melalui model inkuiri terbimbing. Metode penelitian yang digunakan adalah analisis kuantitatif dimana data dibuat dalam bentuk persentase. Sampel penelitian 10 orang guru IPA Biologi yang berasal dari 5 SMP di Balikpapan. Hasil penelitian ini menunjukan kurangnya pemahaman guru terkait perangkat pembelajaran berbasis inkuiri (Silabus, RPP, Handout, LKPD, Media dan Evaluasi) terbimbing dan banyaknya masalah yang dihadapi oleh guru pada saat pengembangan perangkat pembelajaran IPA Biologi mulai dari Silabus, RPP, Handout, LKPD, Media dan Evaluasi. Berdasarkan hasil penelitian tersebut disimpulkan bahwa $70 \%$ guru pemahaman terkait perangkat pembelajaran masuk dalam kategori kurang dan $75 \%$ guru mengalami permasalahan pada saat mengembangkan perangkat pembelajaran berbasis inkuiri terbimbing. Dari hasil penelitian tersebut disimpulkan bahwa perlunya mengadakan sosialisasi dan mengembangkan perangkat pembelajaran berbasis inkuiri terbimbing IPA Biologi SMP.
\end{abstract}

Kata Kunci: Analisis, Guru, Perangkat Pembelajaran, Inkuiri Terbimbing, Biologi

\section{Abstract}

This study aims to determine the understanding of teachers related learning tools developed through guided inquiry learning model and to find out what problems faced by teachers while developing learning devices through guided inquiry model. The research method used is quantitative analysis where data is made in the form of percentage. Research sample of 10 IPA Biology teachers from 5 junior high schools in Balikpapan. The results of this study indicate a lack of understanding of teachers related to inquiry-based learning tools (Silabus, RPP, Handout, LKPD, Media and Evaluation) guided and the many problems faced by teachers at the time of development of biology science learning devices ranging from Silabus, RPP, Handout, LKPD, Media and Evaluation. Based on the result of the research, it can be concluded that $70 \%$ of teachers related to learning tools are in less category and 75\% of teachers experience problems when developing guided inquiry based learning device. From the results of this study concluded that the need to hold socialization and develop learning tools based inquiry of science-based biology junior high school

Keywords: Analysis, Teachers, Learning Devices, Guided Inquiry, Biology

\section{Pendahuluan}

Pendidikan memiliki peranan penting dalam kemajuan suatu bangsa. Kemajuan suatu Negara dapat diketahui dari bagaimana pendidikan agar mampu membentuk sumber daya manusia yang berkualitas. Pembaharuan pendidikan harus selalu dilakukan untuk meningkatkan kualitas pendidikan suatu bangsa. Pendidikan adalah usaha sadar dan terencana untuk mewujudkan suasana belajar dan proses pembelajaran agar pesertadidik secara aktif mengembangkan potensi dirinya untuk memiliki kekuatan spiritual keagamaan, pengendalian diri, kepribadian, kecerdasan, akhlak mulia, serta keterampilan yang diperlukan dirinya, masyarakat, bangsa dan negara. (UU RI No 20 Tahun 2003) [1].

Kurikulum 2013 dikembangkan ddengan alasan untuk melakukan, Penguatan pola pembelajaran yang berpusat pada peserta didik. Peserta didik harus memiliki pilihan pilihan terhadap materi yang dipelajari dan gaya belajarnya (learning style) untuk memiliki kompetensi yang sama; Penguatan pola pembelajaran interaktif (interaktif guru peserta didik-masyarakat lingkungan alam, sumber/media lainnya); Penguatan pola pembelajaran secara jejaring (peserta didik dapat menimba ilmu dari siapas aja dan dari mana saja yang dapat dihubungi serta diperoleh melalui internet). Penguatan pembelajaran aktif - mencari (pembelajaran siswa aktif mencari semakin diperkuat dengan pendekatan pembelajaran saintifik). Penguatan pola belajar sendiri dan kelompok (berbasis tim). Penguatan pembelajaran berbasis multimedia. Penguatan pola pembelajaran berbasis klasikal - missal dengan tetap memperhatikan pengembangan potensi khusus yang dimiliki setiap peserta didik; Penguatan pola pembelajaran ilmu pengetahuan jamak(multidisciplines); Penguatan pola pembelajaran kritis [2].

Pembelajaran Biologi seharusnya menekankan pada pemberian pengalaman belajar langsung untuk mengembangkan kompetensi agar siswa memperoleh 
pemahaman yang lebih mendalam tentang dirinya sendiri dan alam sekitar. Sehingga dalam pembelajaran hendaknya menyediakan berbagai pengalaman belajar untuk memahami konsep dan proses Biologi [3].

Ditinjau dari kurikulum 2013, pembelajaran Biologi yang berkembang secara dinamis perlu adanya pendekatan saintifik (scientific approach) dan salah satunya adalah mengunakan model inkuiri. Menurut (Ronald, 1998) Inquiry : Learning from the Past with an Eye on the Future mengungkapkan bahwa inkuiri terbimbing masih memegang peranan guru dalam memilih materi atau bahasan, pertanyaan dan menyediakan materi, akan tetapi siswa diharuskan untuk mendesain atau merancang penyelidikan, menganalisa hasil sampai kepada kesimpulan. Untuk menerapkan model pembelajaran inkuiri terbimbing perlunya seorang guru yang kratif dalam mengembangkan perangkat pembelajaran dengan langkah-langkah inkuiri terbimbing dimulai dari Silabus, RPP, Handout, Media, LKPD dan Evaluasi [4]. Dimana perangkat pembelajaran yang dikembangkan oleh guru diharapkan mampu meningkatkan hasil belajar siswa dan memberikan pengalaman belajar kepada siswa terkait materi yang diajarkan [5].

Perlunya suasana belajar yang menyenangkan dan memberikan pengalaman bagi siswa saat proses pembelajaran IPA Biologi berlangsung, terutama bagi siswa SMP. Tingginya rasa ingin tahu pada siswa SMP akan sangat membantu jika proses belajar mengajar menggunakan model Inkuiri terbimbing sehingga siswa-siswi dapat belajar dari lingkungan dan memahami setiap peristiwa alam yang terjadi dilingkungan sekitarnya [6]. Berdasarkan hasil observasi yang telah lakukan di 5 SMP kota Balikpapan membuktikan bahwa rata-rata guru guru tidak menerapkan model pembelajaran inkuiri pada saat proses belajar mengajar berlangsung terutama pada materi yang membutuhkan pembuktian, hal ini disebabkan karena kurangnya pengetahuan akan model pembelajaran dan tidak dapat merealisasikan langkah-langkah kerja inkuiri ke dalam perangkat perangkat pembelajaran.

Berdasarkan latar belakang maka tujuan dari penelitian ini sebagai berikut untuk mengetahui bagaimana pemahaman guru terkait perangkat pembelajaran IPA Biologi yang dikembangkan melalui model inkuiri terbimbing, serta untuk mengetahui apakah permasalahan guru terkait pegembangan perangkat pembelajaran IPA Biologi melalui model inkuiri terbimbing di SMP.

\section{Metode Penelitian}

Penelitian ini hanya terbatas pada analisis kebutuhan (need assessment) yang bersumber dari hasil observasi awal di lapangan. Teknik pengumpulan data dalam penelitian ini menggunakan instrument analisis kebutuhan untuk guru [7]. Untuk mengetahui kenyataan di lapangan yang berhubungan dengan proses pembelajaran yang selama ini dilaksanakan, peneliti melakukan observasi di lima sekolah yang dipilih secara acak untuk menggali potensi dan masalah yang mungkin muncul dalam proses pembelajaran, yaitu: SMPN 2 Balikpapan, SMPN 4 Balikpapan, SMPN 12 Balikpapan, SMP 22 Balikpapan, SMP Kartika Balikpapan. Masing- masing sekolah memiliki karateristik yang berbeda sesuai dengan lingkungan dan kondisi sekolah tersebut. Respoden dari kelima sekolah seluruh guru IPA Biologi SMP yang dipilih secara acak untuk memberikan informasi mengenai proses pembelajaran di sekolah. Instrument penelitian berupa kuesioner yang diisi responden akandianalisis secara kuantitatif (Persentase) dan deskriptif (Kualitatif).

\section{Hasil dan Pembahasan}

Berdasarkan penelitian yang telah dilakukan terkaitpemahaman guru tentang perangkat pembelajaran IPA Biologi berbasis Inkuiri terbimbing dan permasalahan guru terkait pemahaman guru mengembangkan perangkat pembelajaran berbasis inkuiri terbimbing. Untuk lebih jelasnya dapat dilihat pada Tabel berikut ini:

Tabel 1. Pemahaman guru terkait perangkat pembelajaran IPA Biologi berbasis Inkuiri terbimbing

\begin{tabular}{|l|l|c|c|c|}
\hline \multirow{2}{*}{ No } & \multirow{2}{*}{$\begin{array}{c}\text { Perangkat } \\
\text { pembelajaran }\end{array}$} & \multicolumn{3}{|c|}{ Penilaian } \\
\cline { 3 - 5 } & Kurang (\%) & Cukup (\%) & Baik (\%) \\
\hline 1 & Silabus & $85,71 \%$ & $14,28 \%$ & $0.00 \%$ \\
\hline 2 & RPP & $57,14 \%$ & $28,57 \%$ & $14,28 \%$ \\
\hline 3 & Bahan Ajar & $57,14 \%$ & $28,57 \%$ & $14,28 \%$ \\
\hline 4 & LKS & $71,42 \%$ & $14,28 \%$ & $14,28 \%$ \\
\hline 5 & Media & $57,14 \%$ & $28,57 \%$ & $14,28 \%$ \\
\hline 6 & Evaluasi & $85,71 \%$ & $14,28 \%$ & $0.00 \%$ \\
\hline
\end{tabular}

Sumber : Hasil Penelitian, 2017

Berdasarkan tabel di atas membuktikan bahwa kurangnya pemahaman guru SMP terkait perangkat pembelajaran berbasis inkuiri terbimbing, pada indikator silabus guru $85,71 \%$ berada pada kategori kurang, hal tersebut menunjukkan bahwa guru tidak memahami merealisasikan model inkuiri terbimbing dengan silabus. Perangkat RPP 57,14\% guru berada pada kategori kurang, hal tersebut membuktikan bahwa banyak guru yang tidak memahami RPP berbasis inkuiri terbimbing sehingga perlunya solusi untuk memecahkan masalah tersebut. Perangkat LKPD 71,42\% guru berada pada kategori kurang, hal tersebut membuktikan bahwa kurangnga pemahaman guru terkait menyusun LKPD berbasis inkuiri terbimbing, jika dilihat dari kebutuhan siswa LKPD sangat penting untuk menunjang proses pembelajaran di dalam kelas dan membuat siswa lebih aktif pada saat proses pembelajaran berlangsung. Media pembelajaran 57,14\% guru pada kategori kurang hal tersebut menunjukkan guru kurang paham menentukan media yang digunakan untuk pembelajaran yang memerlukan pembuktian, jika dilihat dari pentingnya media pada saat proses berlangsungnya pembelajaran untuk menarik minat siswa dan memancing siswa untuk merumuskan masalah terkait materi yang akan disampaikan sehingga perlunya membuat media yang kreatif dan menarik berbasis inkuiri terbimbing. Evaluasi pembelajaran $85,71 \%$ guru berada pada kategori kurang hal itu menunjukkan bahwa kurangnya pemahaman guru membuat evaluasi pembelajaran untuk mengukur keberhasilan siswa, evaluasi sangat penting dilakukan untuk 
mengukur keberhasilan siswa dan menjadi tolak ukur keberhasilan dalam proses pembelajaran. Pemahaman guru SMP khususnya IPA Biologi terkait perangkat pembelajaran tergolong sangat rendah karena kurangnya literatur dan informasi yang didapat oleh guru, sehingga perlunya mengadakan sosialisasi dan paparan terkait perangkat pembelajaran yang dikembangkan melalui model inkuiri terbimbing. Hasil sosialisasi tersebut diharapkan guru mampu memahami perangkat pembelajaran yang dikembangkan melalui model inkuiri terbimbing. Sehingga dapat meningkatkan hasil belajar siswa dengan cara praktikum hal itu seturut dengan pendapat Chodidah (2012), menyatakan bahwa proses pembelajaran melalui model Inkuiri terbimbing sangatlah penting untuk membentuk karakter siswa dan meningkatkan pemahaman siswa terkait materi IPA Biologi [8].

Tabel 2. Permasalahan guru terkait pengembangan perangkat pembelajaran IPA Biologi berbasis inkuiri terbimbing

\begin{tabular}{|l|l|c|c|c|}
\hline \multirow{2}{*}{ No } & \multirow{2}{*}{$\begin{array}{c}\text { Perangkat } \\
\text { pembelajaran }\end{array}$} & \multicolumn{3}{|c|}{ Penilaian } \\
\cline { 3 - 5 } & Kurang (\%) & Cukup (\%) & Baik (\%) \\
\hline 1 & Silabus & $71,42 \%$ & $14,28 \%$ & $14,28 \%$ \\
\hline 2 & RPP & $57,14 \%$ & $28,57 \%$ & $14,28 \%$ \\
\hline 3 & Bahan Ajar & $57,14 \%$ & $28,57 \%$ & $14,28 \%$ \\
\hline 4 & LKS & $71,42 \%$ & $14,28 \%$ & $14,28 \%$ \\
\hline 5 & Media & $57,14 \%$ & $28,57 \%$ & $14,28 \%$ \\
\hline 6 & Evaluasi & $85,71 \%$ & $14,28 \%$ & $0.00 \%$ \\
\hline
\end{tabular}

Sumber Hasil Penelitian 2017

Berdasarkan tabel di atas membuktikan bahwa banyak permasalahan yang dihadapi guru SMP IPA Biologi terkait pengembangan perangkat pembelajaran berbasis inkuiri terbimbing, pada indikator silabus guru $71,42 \%$ berada pada kategori kurang, hal tersebut menunjukkan bahwa guru tidak memahami merealisasikan model inkuiri terbimbing dengan silabus. Perangkat RPP 57,14\% guru berada pada kategori kurang, hal tersebut membuktikan bahwa banyak guru yang tidak memahami RPP berbasis inkuiri terbimbing sehingga perlunya solusi untuk memecahkan masalah tersebut. Perangkat LKS 57,14\% guru berada pada kategori kurang, hal tersebut membuktikan bahwa kurangnga pemahaman guru terkait menyusun LKPD berbasis inkuiri terbimbing, jika dilihat dari kebutuhan siswa LKPD sangat penting untuk menunjang proses pembelajaran di dalam kelas dan membuat siswa lebih aktif pada saat proses pembelajaran berlangsung sejalan degan hsil penelitian yang telah dilakukan oleh Hakim (2009) terkait perangkat pembelajaran [9]. Media pembelajaran 57,14\% guru pada kategori kurang hal tersebut menunjukkan guru kurang paham menentukan media yang digunakan untuk pembelajaran yang memerlukan pembuktian, jika dilihat dari pentingnya media pada saat proses berlangsungnya pembelajaran untuk menarik minat siswa dan memancing siswa untuk merumuskan masalah terkait materi yang akan disampaikan sehingga perlunya membuat media yang kreatif dan menarik berbasis inkuiri terbimbing.
Evaluasi pembelajaran $71,42 \%$ guru berada pada kategori kurang hal itu menunjukkan bahwa kurangnya pemahaman guru membuat evaluasi pembelajaran untuk mengukur keberhasilan siswa, evaluasi sangat penting dilakukan untuk mengukur keberhasilan siswa dan menjadi tolak ukur keberhasilan dalam proses pembelajaran. Permasalahan guru SMP khususnya IPA Biologi terkait pengembangan perangkat pembelajaran tergolong sangat banyak karena kurangnya latihan dan pemahaman terkait perangkat dan model pembelajaran, sehingga perlunya mengembangkan perangkat pembelajaran kemudian disosialisasikan kepada guru yang bermasalah. Hal tersebut sejalan dengan penelitian yang pernah dilakukan oleh Idha [10]. Dengan berlangsungnya kegiatan tersebut diharapkan guru SMP IPA Biologi memiliki kemampuan dalam mengembangkan perangkat pembelajaran sesuai dengan materi yang diajarkan. Perangkat pembelajaran yang digunakan oleh guru saat mengajar sangat mempengaruhi hasil belajar siswa dan karakter siswa, sehingga perlunya seorang guru dalam membuat perangkat sebelum mengajar mulai dari Silabus, RPP, Handout, Media, LKPD dan Evaluasi

-

\section{Késimpulan dan Saran}

Berdasarkan hasil penelitian yang telah dilakukan dapat disimpulkan bahwa pemahaman guru terkait perangkat Silabus, RPP, LKPD, Handout, Media,Evaluasi rata-rata $70 \%$ guru dalam kategori kurang. Permasalahan guru terkait pengembangan perangkat Silabus, RPP, LKPD, Handout, Media,Evaluasi rata-rata 75\% guru dalam kategori kurang.

Berdasarkan hasil penelitian yang dilakukan rekomendasi adalah perlunya pengembangan perangkat pembelajaran terkait perangkat Silabus, RPP LKPD, Handout Media dan Evaluasi yang lebih baik, serta perlunya pengembangan perangkat pembelajaran IPA Biologi melalui model inkuiri terbimbing.

\section{Daftar Pustaka}

[1] Depdikbud. (2013). Kurikulum, Standar Kompetensi Mata Pelajaran Biologi Sekolah Menengah Atas. Jakarta.

[2] Science, N. A. (2000). Inquiry and national science educational standars. Wasington: National Academic. Press.

[3] Bell, B. H. (2008). The Many Level Inquiry. Washington.

[4] Ronald, B. (1998). Learning From the past with an eye on the future. Linclon: University Of Nebraska.

[5] Tindangen, M. (2016). Pengembangan Perangkat pembelajaran berbasis inquiry terbimbing untuk meningkatkan kemampuan berfikir tingkat tinggi siswa SMP dan SMA. Samarinda: LP2M Universitas Mulawarman.

[6] Dahar. (1989). Teori-Teori elajar. Jakarta: Erlangga.

[7] Sugiyono. (2014). Statistik Pengembangan. Jakarta: Erlangga

[8] Chodidah. (2012). Pengembangan Perangkat Pembelajaran Fisika menggunakan model Guided Inquiry yang dilengkapi dengan penilaian portofolio pada materi gerak pada tumbuhan. Malang: Jurnal Pendidikan Fisika.

[9] Hakim. (2009). Perencanaan Pembelajaran. Bandung: CV: Wacana Prima

[10] Idha, C. (2008). Meningkatkan pemahaman konsep mata pelajaran Biologi Melalui Perfomance Assesment. Bandung: Jurnal Pendidikan Inovative. 